Mycologia

\title{
Combining morphological and phylogenetic analyses to unravel systematics in Geastrum sect. Schmidelia
}

\author{
Juan Carlos Zamora, Francisco de Diego Calonge \& María P. Martín
}

To cite this article: Juan Carlos Zamora, Francisco de Diego Calonge \& María P. Martín (2014) Combining morphological and phylogenetic analyses to unravel systematics in Geastrum sect. Schmidelia, Mycologia, 106:6, 1199-1211, DOI: 10.3852/14-072

To link to this article: https://doi.org/10.3852/14-072

+ View supplementary material ๘

曲 Published online: 20 Jan 2017.

Submit your article to this journal $\widetilde{1}$

Џll Article views: 35

Q View related articles 두

View Crossmark data $₫$ 
Mycologia, 106(6), 2014, pp. 1199-1211. DOI: 10.3852/14-072

(C) 2014 by The Mycological Society of America, Lawrence, KS 66044-8897

\section{Combining morphological and phylogenetic analyses to unravel systematics in Geastrum sect. Schmidelia}

Juan Carlos Zamora ${ }^{1}$

Francisco de Diego Calonge

María P. Martín

Real Jardín Botánico-CSIC, Plaza de Murillo 2, E-28014, Madrid, Spain

\begin{abstract}
Systematics of the recently proposed Geastrum sect. Schmidelia are addressed through statistical analyses of quantitative morphological variables and phylogenetic reconstructions based on a multilocus approach. Emphasis is given to the taxonomic placement of G. schmidelii var. parvisporum. This variety is found to be not phylogenetically close to $G$. schmidelii var. schmidelii, the type species of $G$. sect. Schmidelia, and it therefore is excluded from this section, taxonomically raised to species rank (as $G$. parvisporum) and included as a member of $G$. sect. Hariotia. A second species in G. sect. Schmidelia is recognized and formally described as $G$. senoretiae. It is characterized by small basidiomata, non-hygrometric exoperidium, subsessile endoperidium and finely plicate, indistinctly delimited peristome, so far known only from Spain. Photographs and drawings are included, along with a comparison of morphologically close taxa. The presence of sclerified basidia in the mature gleba, previously not reported in the genus, is commented on.
\end{abstract}

Key words: ANOVA, atp6, Geastraceae, Geastrum senoretiae, ITS, Mediterranean Basin, nrLSU, rpb1, taxonomy, Tukey's test

\section{INTRODUCTION}

Geastrum Pers.: Pers. (Persoon 1801) is the most diverse genus of the order Geastrales (Hosaka et al. 2007), a relatively basal group of Agaricomycetes that, according to Hosaka et al. (2007) and Hosaka and Castellano (2008), includes most of the earthstars (Geastraceae), the cannon-ball fungi (Sphaerobolaceae) and some hypogeous fungi (Schenellaceae and Sclerogastraceae).

Geastrum is a widespread genus and more diverse than usually thought. Although the last Dictionary of Fungi (Kirk et al. 2008) considers about 50 species in Geastrales worldwide, studies (Zamora et al. 2014) estimated not less than 100-120 taxa in this genus.

Submitted 21 Mar 2014; accepted for publication 30 Jun 2014.

${ }^{1}$ Corresponding author. E-mail: jczamora@rjb.csic.es
More than 10 new taxa of Geastrum have been proposed since 2000 (Baseia and Milanez 2003, Calonge and Mata 2004, Dörfelt et al. 2004, Calonge et al. 2005, Douanla-Meli et al. 2005, Baseia and Calonge 2006, Zamora and Calonge 2007, Fazolino et al. 2008, Kuhar and Papinutti 2009, Hemmes and Desjardin 2011, Kuhar et al. 2013), showing that an important number of taxa are still undescribed.

In Europe the genus has been studied in detail. Sunhede (1989) has made the most thorough study so far, recognizing 24 European Geastrum species, plus Trichaster melanocephalus Czern., which nevertheless is considered within Geastrum by most modern authors (e.g. Calonge 1998, Sarasini 2005, Kasuya et al. 2012). Calonge and Zamora (2003) recorded $G$. arenarium Lloyd as new for the European mycobiota, and Zamora and Calonge (2007) described $G$. parvistriatum J.C. Zamora \& Calonge as a new species from Spain. Jeppson et al. (2013) revised the European species of Geastraceae based on a molecular approach, contributing to solving the taxonomy of these taxa. They considered Radiigera Zeller a synonym of Geastrum, separated G. pseudostriatum Hollós (= G. hollosii V.J. Staněk) from G. berkeleyi Massee and found European specimens of $G$. xerophilum Long ex Desjardin, as well as a possibly undescribed species morphologically close to $G$. floriforme Vittad. and phylogenetically close to $G$. rufescens Pers.:Pers. Thus, Geastrum currently encompasses 31 species in Europe.

Zamora et al. (2014) presented a revision of the infrageneric classification of the genus and reevaluated the morphological characters that seemed useful for distinguishing the different infrageneric taxa, considering a total of 14 sections worldwide. One of these is Geastrum sect. Schmidelia J.C. Zamora, which contains a single described species, G. schmidelii Vittad. This species traditionally was considered close to G. elegans Vittad., G. pectinatum Pers. and $G$. striatum DC., mainly due to its combination of a smooth endoperidia surface and a sulcate peristome. For instance, Staněk (1958) included the mentioned species under his subsect. Sulcostomata V.J. Staněk, with $G$. pectinatum as type. Nevertheless Zamora et al. (2014) showed that the name subsect. Sulcostomata should be restricted to the group formed by $G$. glaucescens Speg., G. parvistriatum, G. pectinatum and G. striatum, due to both molecular and morphological data, such as the presence of a well developed, 
powdery mesoperidial layer, clearly stalked endoperidial body and slender basidia. Moreover phylogenetic analyses placed G. elegans and G. schmidelii not closely related with subsect. Sulcostomata. Geastrum elegans was separated in a monospecific section Elegantia J.C. Zamora, with a well developed, powdery mesoperidium but a sessile endoperidial body and stout basidia. Finally, as noted above, G. schmidelii also was placed in a separate section named Schmidelia, which is characterized, by a poorly developed, not powdery mesoperidium, more or less stalked endoperidial body and stout basidia. As indicated, basidium morphology in Geastrum is of taxonomic interest, but the state in which mature basidia can be observed seems to be of short duration. Basidia normally disintegrate in mature basidiomata, and only few remnants may persist in the mature gleba mass. Therefore, it is difficult to find specimens in herbaria in a proper basidial state (Sunhede 1989).

Geastrum schmidelii var. parvisporum G. Moreno, Altés \& Dios is another taxon that might be thought to be included in Geastrum sect. Schmidelia. This variety was proposed by Dios et al. (2000) based on Argentinean specimens, and it is differentiated by its clearly smaller basidiospores, while the remaining morphological characters seem to be similar to those of G. schmidelii var. schmidelii. However, because the type material of this variety was not previously included in any molecular phylogenetic analyses and the basidiospore features seem to be important for infrageneric classification purposes (Zamora et al. 2014), the taxonomic position of this variety remains uncertain.

Zamora et al. (2014) also indicated a high number of undescribed species, one of them belonging to Geastrum sect. Schmidelia. The species was found growing with other species such as G. minimum Schwein. Further Iberian specimens were found during the revision of the MA-Fungi herbarium (Madrid, Spain), but these were erroneously determined as G. elegans and G. kotlabae V.J. Staněk. It is well known that Mediterranean areas are one of the biomes that harbor high species diversity (Médail and Quézel 1997, Myers and Cowling 1999). As a result, it is not surprising that new species come to light.

The two specific aims of the present work are (i) to unravel the taxonomic position of G. schmidelii var. parvisporum and (ii) to describe the new species in Geastrum sect. Schmidelia by establishing the morphological differences and the phylogenetic relationships with other morphologically similar species.

\section{MATERIAL AND METHODS}

Sampling.-The present study involves the taxa already known to be part of Geastrum sect. Schmidelia (G. schmidelii and one newly described species), one taxon that putatively belongs to this section ( $G$. schmidelii var. parvisporum) and other taxa that can be confused with the new species because they share some morphological similarities ( $G$. elegans, G. kotlabae, G. minimum). The studied specimens are deposited in AH, CORD, MA-Fungi, UPS, S, S. Sunhede's and J.C. Zamora's herbaria. Public herbarium acronyms follow Thiers [continuously updated]. The complete list of studied collections is included (SUPPLEMENTARY APPENDIX).

Molecular study.-General methodology for the molecular study was carefully described in Zamora et al. (2014) and therefore briefly indicated next. DNA was extracted from the gleba mass of mature fruit bodies, with either E.Z.N.A. ${ }^{\circledR}$ Fungal DNA Miniprep Kit (Omega Biotek, USA) or DNeasy ${ }^{\circledR}$ Plant Mini Kit (QIAGEN, Germany). Four DNA regions were included in the present study, the complete ITS (ITS1, 5.8S, and ITS2) nrDNA region, the first part of the 28S nrDNA region (LSU) and genes encoding the largest subunit of the RNA polymerase II ( $r p b 1)$ and subunit 6 of the ATP synthase (atp6). Primers used for amplifying these regions were ITS1F (Gardes and Bruns 1993) and ITS4 (White et al. 1990) for the ITS region, LR0R and either LR5 or LR7 (Vilgalys and Hester 1990) for LSU, gRPB1-A (Stiller and Hall 1997)/fRPB1-C (Matheny et al. 2002) and RPB1GEA-1F/RPB1GEA-2r (Zamora et al. 2014) for $r p b 1$, and atp6-3/atp6-2 (Kretzer and Bruns 1999) for atp6. Cycling parameters for ITS follow Martín and Winka (2000) and for LSU and rpbl are described in Zamora et al. (2014) and for atp6 are those of Kretzer and Bruns (1999). Sequencing was done by Macrogen (the Netherlands/South Korea).

Four samples of the new species from different geographical origins were included, as well as five specimens of G. schmidelii. All GenBank DNA sequences of the cited DNA regions, determined as G. schmidelii, also were used, with exception of KC582008, which contained an unexpected number of changes in conserved parts of the alignment, likely to be PCR or sequencing errors. The holotype of $G$. schmidelii var. parvisporum was added to assess the phylogenetic position of this taxon, and thus to decide the most appropriate taxonomic placement for it, together with two other similar samples in terms of morphology and molecular sequence data already included in Zamora et al. (2014). Since the new species was confused in MA-Fungi with G. elegans and G. kotlabae, and it was found growing together with the superficially similar G. minimum, samples of these taxa also were added, as well as sequences of two specimens of G. fornicatum (Huds.) Hook. that were used as outgroup, following Zamora et al. (2014). Data of all the specimens included in molecular analyses are summarized (TABLE I).

DNA sequences were edited and assembled to obtain consensus with Sequencher 4.1.4 (Gene Codes, USA). Sequences were aligned through the MAFFT (Katoh et al. 2002) online server, setting the FFT-NS-i strategy, and manually adjusted with BioEdit (Hall 1999), except for the atp6 dataset that was directly aligned with BioEdit when transcribed to protein ("toggle translation"). Ambiguously 
TABLE I. Specimens included in molecular analyses, with related information of geographical origins, voucher specimens and GenBank sequences

\begin{tabular}{|c|c|c|c|c|c|c|}
\hline \multirow[b]{2}{*}{ Taxon } & \multirow{2}{*}{$\begin{array}{c}\text { Country and state/ } \\
\text { province }\end{array}$} & \multirow[b]{2}{*}{ Herbarium voucher } & \multicolumn{4}{|c|}{ GenBank accession No. } \\
\hline & & & ITS & LSU & $r p b 1$ & atp6 \\
\hline G. elegans & Spain, Ávila & Zamora 189 & KF988366 & KF988488 & KF988623 & KF988758 \\
\hline G. elegans & Sweden, Gotland & UPS F-560810 & KF988367 & KF988489 & KF988624 & KF988759 \\
\hline G. fornicatum & Spain, Lérida & MA-Fungi 30749 & KF988375 & KF988497 & KF988632 & KF988767 \\
\hline G. fornicatum & Spain, Valladolid & Zamora 255 & KF988374 & KF988496 & KF988631 & KF988766 \\
\hline G. kotlabae & Spain, Madrid & MA-Fungi 39563 & KF988385 & KF988510 & KF988645 & KF988778 \\
\hline G. kotlabae & Spain, Valladolid & Zamora 440 & KF988386 & KF988511 & KF988646 & KF988779 \\
\hline G. minimum agg. & Spain, Madrid & Zamora 191 & KF988400 & KF988528 & KF988663 & KF988795 \\
\hline G. minimum agg. & Spain, Madrid & MA-Fungi 31530 & KF988404 & KF988532 & KF988667 & KF988799 \\
\hline G. minimum agg. & Sweden, Gotland & MA-Fungi 86669 & KF988405 & KF988533 & KF988668 & KF988800 \\
\hline G. minimum agg. & Sweden, Öland & Sunhede 7746 & KF988401 & KF988529 & KF988664 & KF988796 \\
\hline G. minimum agg. & USA, Arizona & MICH 28119 & KF988403 & KF988531 & KF988666 & KF988798 \\
\hline G. minimum agg. & USA, Wisconsin & MICH 72010 & KF988402 & KF988530 & KF988665 & KF988797 \\
\hline G. parvisporum & Argentina, Catamarca & AH 19559 (Туре) & KJ588614 ${ }^{\mathrm{a}}$ & KJ588620 & KJ588626 & KJ588632 \\
\hline G. parvisporum & Argentina, La Rioja & MA-Fungi 83793 & KF988461 & KF988596 & KF988731 & KF988862 \\
\hline G. aff. parvisporum & Argentina, La Rioja & MA-Fungi 83794 & KF988462 & KF988597 & KF988732 & KF988863 \\
\hline G. schmidelii & Spain, Burgos & Zamora 188 & KJ588617 & KJ588623 & KJ588629 & KJ588635 \\
\hline G. schmidelii & Spain, Madrid & Zamora 199 & KJ588618 & KJ588624 & KJ588630 & KJ588636 \\
\hline G. schmidelii & Spain, Madrid & Zamora 279 & KF988434 & KF988564 & KF988699 & KF988831 \\
\hline G. schmidelii & Spain, Valencia & Zamora 313 & KJ588619 & KJ588625 & KJ588631 & KJ588637 \\
\hline G. schmidelii & Sweden, Öland & Sunhede 7742 & KF988435 & KF988565 & KF988700 & KF988832 \\
\hline G. schmidelii & England & $\mathrm{K}(\mathrm{M}) 59281$ & EU784247 & EU784247 & - & - \\
\hline G. schmidelii & Sweden, Öland & L 837173 & JN845121 & JN845239 & - & JN845363 \\
\hline G. schmidelii & Sweden, Öland & S F-35636 & JN845122 & JN845240 & - & JN845364 \\
\hline G. schmidelii & Sweden & MJ8246 & - & KC582007 & - & - \\
\hline G. schmidelii & Sweden & MJ8449 & KC582006 & KC582006 & - & - \\
\hline G. senoretiae & Spain, Cáceres & Zamora 145 & KF988458 & KF988593 & KF988728 & KF988859 \\
\hline G. senoretiae & Spain, Ciudad Real & MA-Fungi 39564 & KJ588615 & KJ588621 & KJ588627 & KJ588633 \\
\hline G. senoretiae & Spain, Jaén & MA-Fungi 86915 (Type) & KF988459 & KF988594 & KF988729 & KF988860 \\
\hline G. senoretiae & Spain, Orense & MA-Fungi 32382 & KJ588616 & KJ588622 & KJ588628 & KJ588634 \\
\hline
\end{tabular}

${ }^{a}$ New sequences indicated in boldface.

aligned parts of the ITS dataset were removed with Gblocks (Castresana 2000), allowing all gap positions when not ambiguous but only a maximum of four contiguous nonconserved positions. The remaining insertion/deletion events (indels) were coded in FastGap 1.2 (Borchsenius 2007), following the simple indel coding of Simmons and Ochoterena (2000), in a separate binary data subset. Data matrices are available in TreeBase (TB2:S15502).

Phylogenetic analyses were performed with maximum likelihood (ML) and Bayesian inference (BI) approaches. Dataset congruence was analysed with a preliminary parsimony bootstrapping in PAUP* 4.0b10 (Swoford 2003) and performing 1000 non-parametric replicates (Felsenstein 1985) with the FAST stepwise-addition option. Conflict among datasets was considered according to Hillis and Bull (1993). When no conflicts were detected, the datasets were concatenated.

Maximum likelihood analysis was conducted in GARLI 2.0 (Zwickl 2006), considering the following partitions: ITS1, 5.8S, ITS2, LSU, rpb1, atp6 and binary coded indels. The GTR $+\mathrm{I}+\Gamma$ model was used for each DNA partition and the symmetric one rate $\mathrm{Mk}$ model for the binary data partition (Lewis 2001). The analysis was repeated twice starting from random trees. Branch support (BS) was assessed performing 1000 nonparametric bootstrap replicates with the thorough bootstrap option of RAxML 7.4.2 (Stamatakis 2006), using the partitioned dataset and default settings for the remaining parameters.

Bayesian inference analysis was performed in MrBayes 3.2 (Ronquist et al. 2012) with the metropolis-coupled Markov chain Monte Carlo $\left(\mathrm{MC}^{3}\right)$ algorithm. The same partitions used in ML analysis were considered here, with topology linked across partitions, but separate model parameters for each subset. Nucleotide substitution models were chosen through jModelTest 2.1 (Darriba et al. 2012) with the Akaike information criterion (AIC). For the binary data subset of coded indels (restriction sites) the F81 model was used. Four parallel runs were used, each one starting with a random tree, with six chains, and length preset to $10^{7}$ generations, sampling every 100th tree. The analysis was automatically stopped when the average standard deviation across runs dropped below 0.005. Convergence was also assessed by checking in Tracer 1.5 (Rambaut et al. 2013) that values of effective sample size (ESS) for each parameter 
were $\geq 200$. The first $25 \%$ of the analysis was discarded as burn-in. The 50\% majority-rule tree including branch lengths and posterior probabilities (PP) was calculated from the post-burn-in trees. Problems with convergence and overestimation of branch lengths, reported by Zamora et al. (2014), were not detected with the present dataset, and therefore the default priors were used.

Strength of branch support values follows the criteria and scale defined in Lutzoni et al. (2004). Phylogenetic trees were edited with FigTree 1.3 (Rambaut 2007).

Morphological study.-Methodology for measurements and terminology follow Sunhede (1989) and Calonge (1998), with minor exceptions; due to etymology, the term "hygrometric" is preferred over "hygroscopic" when defining the behavior of the exoperidium to humidity changes, as in Zamora et al. (2013), Zamora et al. (2014).

Macromorphological characteristics refer to dried basidiomata unless otherwise stated. Routine micromorphological study was carried out under a Jeulin light microscope. All basidiospore measurements were made under the $100 \times$ immersion oil objective, with $10 \times$ oculars, in $5 \% \mathrm{KOH}$ solution, including the ornamentation height. For scanning electron microscopy (SEM) small pieces of the endoperidial body and the gleba mass were mounted on a sample holder covered with double-sided adhesive tape, coated with pure gold, and observed with a Hitachi S-3000N microscope. Drawings were performed by direct observation.

The following three continuous and one discrete macromorphological data were measured from 28 basidiomata of G. schmidelii var. parvisporum (G. parvisporum henceforth, see below), 100 of G. schmidelii var. schmidelii, and 55 of the putatively new species: exoperidial diameter (when the exoperidium is forced in horizontal position), endoperidial diameter, stalk height and number of peristome folds. In addition, basidiospore diameter and ornamentation height were measured from 120 basidiospores of G. parvisporum, and 200 basidiospores of $G$. schmidelii and the new species each, from randomly selected basidiomata. We selected these morphological characters because they are some of the most used quantitative characters in the literature and seemed to be reliable a priori for distinguishing the mentioned species. To test this a priori taxonomic usefulness, we first used an analysis of variance (ANOVA) for each character to detect significant differences $(P<$ 0.001) among the three species. When such differences were found, Tukey's honest significant difference (Tukey's HSD) post hock test was used to identify the sample means that were significantly different $(P<0.001)$ from each other. Measurements were represented as boxplots for visual interpretation. Analyses and graphics were performed with R (R Development Core Team 2008).

For the new proposed species a complete description is provided, while for G. parvisporum and G. schmidelii synoptic descriptions are provided because complete descriptions already exist in the literature (Sunhede 1989, Dios et al. 2000). For a better representation of the intraspecific variation, measurements included in the synoptic descriptions are expanded according to the studied specimens.

\section{RESULTS}

Molecular results. - Twenty-four sequences were generated in this study (six from each of the four molecular regions studied) for six specimens. The final matrix had 3527 characters (183 ITS1, 155 5.8S, 196 ITS2, 966 LSU, 1181 rpb1, 707 atp6, 139 indels), of which 2693 were constant and 834 variable. Maximum likelihood analysis with GARLI generated two trees with $\ln \mathrm{L}_{1}=-11022.7844$ and $\ln \mathrm{L}_{2}=-11022.7843$ (best), with an almost identical topology. The ML tree with the best likelihood score is illustrated (FIG. 1).

The nucleotide substitution models selected by jModelTest were HKY $+\Gamma$ for ITS1 and ITS2, K80 for $5.8 \mathrm{~S}$, GTR $+\Gamma$ for LSU and $r p b 1$, and GTR $+\mathrm{I}+\Gamma$ for atp6. Bayesian $\mathrm{MC}^{3}$ analysis was automatically stopped after 1610000 generations. Best likelihood states for each run were $\ln \mathrm{L}_{1}=-11045.21, \ln \mathrm{L}_{2}=-11049.70$, $\ln \mathrm{L}_{3}=-11052.78, \operatorname{lnL_{4}}=-11057.53$. Potential scale reduction factor values for the model parameters were 1.000-1.001. A total of 64404 trees were sampled and the consensus was calculated from the 48304 post burn-in trees. The topology of the consensus tree was almost identical to that of the ML tree, so we only indicate PP values at branches of the ML tree (FIG. 1).

The ML tree (FIG. 1) shows five strongly supported ingroup main clades $(\mathrm{BS}=100 \%, \mathrm{PP}=1.0)$, indicated as different sections. The clade corresponding to sect. Schmidelia is further divided into two highly supported clades $(\mathrm{BS}=100 \%, \mathrm{PP}=1.0$ ) representing two species, G. schmidelii and the newly described $G$. senoretiae. A strongly supported clade (BS $=72 \%, \mathrm{PP}=0.98)$ formed by $G$. elegans (sect. Elegantia) and G. kotlabae (sect. Campestria J.C. Zamora) is sister to sect. Schmidelia, but this last relationship is not so well supported by bootstrapping $(\mathrm{BS}=63 \%)$. Section Geastrum includes all specimens of G. minimum s.l., which are divided in two highly supported clades $(\mathrm{BS}=100 \%, \mathrm{PP}=1.0)$. Finally, sect. Hariotia J.C. Zamora is represented by a strongly supported clade $(\mathrm{BS}=100 \%, \mathrm{PP}=1.0)$, which includes three samples, AH 19559 (holotype of $G$. schmidelii var. parvisporum), MA-Fungi 83793, and MA-Fungi 83794. The samples AH 19559 and MAFungi 83793 were almost identical concerning sequence data and are considered as G. parvisporum s. str., while the sample MA-Fungi 83793 is somewhat different and is regarded as $G$. aff. parvisporum (see Discussion). The clades of sect. Geastrum and sect. Hariotia were placed sister to each other in a strongly supported clade $(\mathrm{BS}=76 \%, \mathrm{PP}=0.98)$.

Morphological results.-ANOVA analyses of the six measured characters (i.e. exoperidial diameter, endoperidial diameter, stalk height, number of peristome folds, basidiospore diameter, ornamentation 


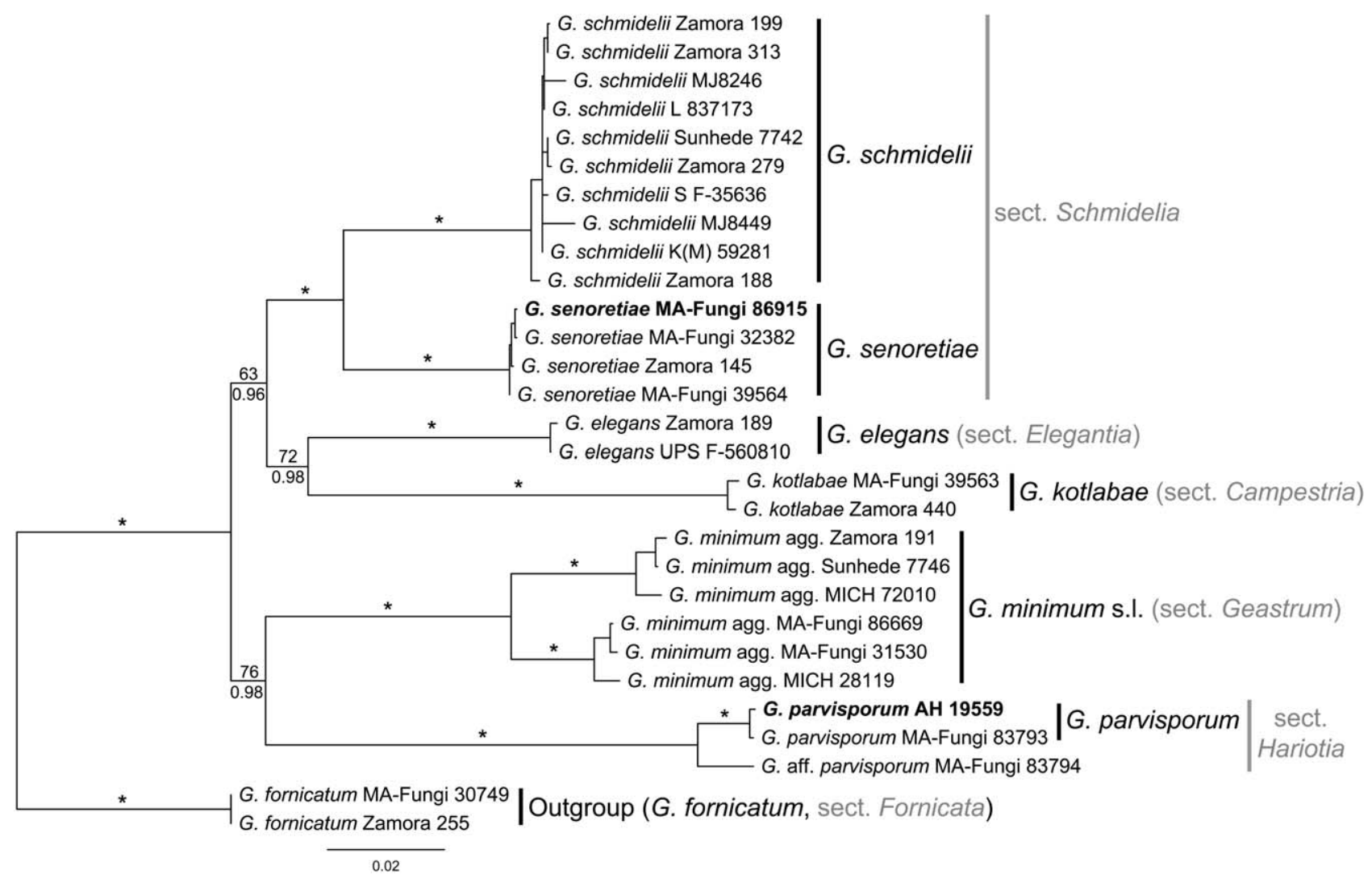

FIG. 1. Maximum likelihood phylogenetic tree of Geastrum sect. Schmidelia and morphologically similar taxa. Numbers above branches indicate maximum likelihood bootstrap (BS) values, and numbers below branches indicate Bayesian posterior probability (PP) values. Asterisks (*) represent branches with $\mathrm{BS}=100 \%$ and $\mathrm{PP}=1$. Type specimens of $G$. senoretiae and $G$. schmidelii var. parvisporum (as G. parvisporum) are marked in boldface.

height) showed significant differences $(P<0.001)$ among G. schmidelii var. parvisporum ( $G$. parvisporum henceforth, see Discussion), G. schmidelii, and $G$. senoretiae (FIG. 2). The exoperidial diameter, endoperidial diameter, and stalk height were significantly smaller in G. senoretiae than in G. parvisporum and $G$. schmidelii (Tukey's HSD test $P<0.001$ ). The number of peristome folds was significantly higher in $G$. senoretiae than in G. parvisporum and G. schmidelii (Tukey's HSD test $P<0.001$ ). However Tukey's HSD test did not reveal significant differences for the exoperidial diameter, endoperidial diameter, stalk height and number of peristome folds between $G$. parvisporum and $G$. schmidelii $(P=0.004, P=0.598, P$ $=0.156, P=0.657$ respectively). For the basidiospore diameter and ornamentation height, Tukey's HSD test found significant differences among the three species in all possible comparisons (FIG. 2E, F). Geastrum parvisporum is the taxon with the smallest basidiospores and lowest warts, G. schmidelii showed the biggest basidiospores and highest warts, and $G$. senoretiae basidiospores are intermediate between these two (FIG. 3A5-C5).
Scanning electron micrographs of the endoperidia surfaces (FIG. 3A4-C4) showed scattered warts, formed by several hyphae glued together, on the endoperidial surface of $G$. parvisporum. These warts are absent in $G$. schmidelii and G. senoretiae. The mesoperidial cover on the endoperidium is almost completely absent in the three taxa, reduced to some collapsed generative hyphae and, sometimes, small bipyramidal crystals, as seen for example in $G$. senoretiae (FIGS. 3C4, 4O). Light microscopy studies of basidiomata of the $G$. senoretiae holotype showed unusual basidia (sclerified basidia) in the mature gleba mass, with thick and somewhat pigmented walls (FIG. 4A-N).

\section{TAXONOMY}

Geastrum parvisporum (G. Moreno, Altés \& Dios) J.C.

Zamora, stat. nov.

FIG. 3A

$\equiv$ G. schmidelii var. parvisporum G. Moreno, Altés \& Dios in Dios et al., Micologia 2000:159. 2000 [basionym]

MycoBank MB808285

Type: ARGENTINA. CATAMARCA: Dpto. Fray M. Esquiu, on soil, 3-VI-1994, H. Villafañe (HOLO- 

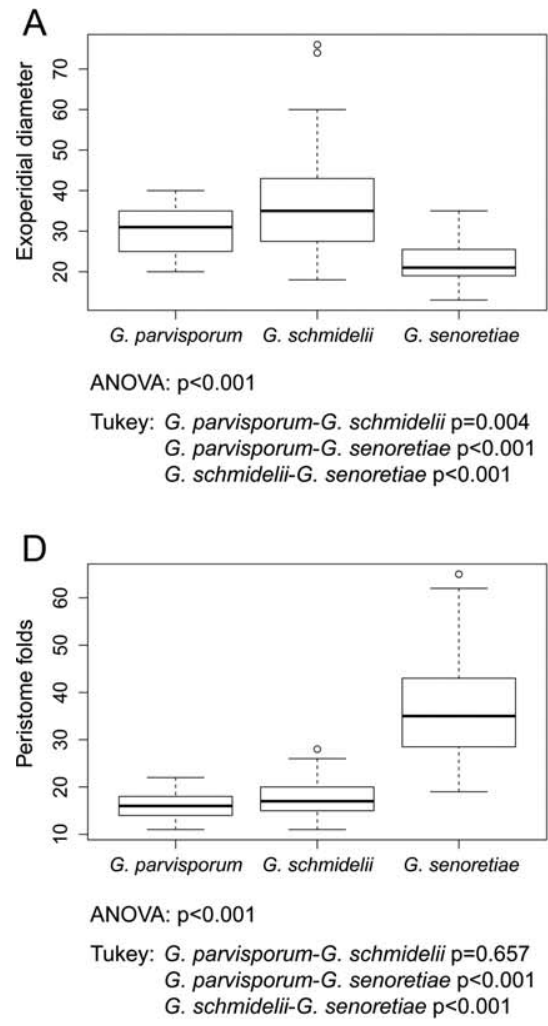
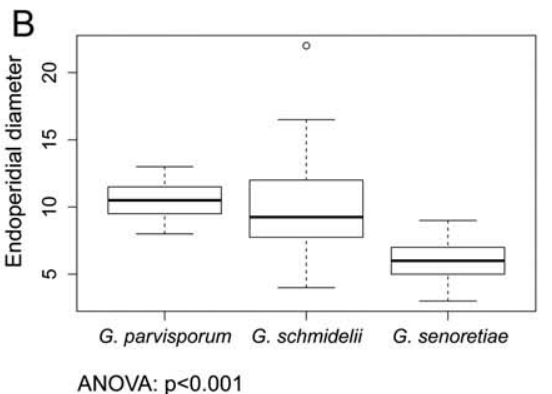

Tukey: $G$. parvisporum-G. schmidelii $p=0.598$ G. parvisporum-G. senoretiae $\mathrm{p}<0.001$ G. schmidelii-G. senoretiae $p<0.001$

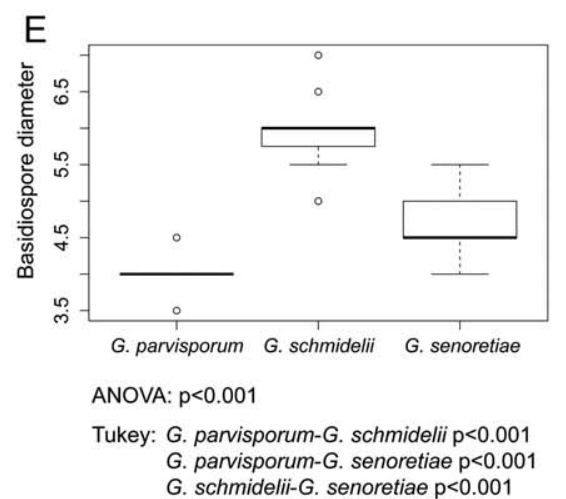

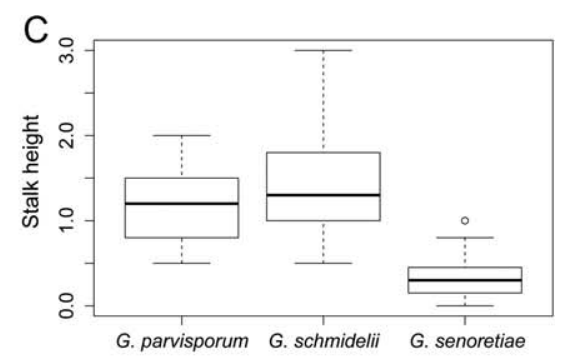

ANOVA: $p<0.001$

Tukey: G. parvisporum-G. schmidelii $p=0.156$ G. parvisporum-G. senoretiae $p<0.001$ G. schmidelii-G. senoretiae $p<0.001$
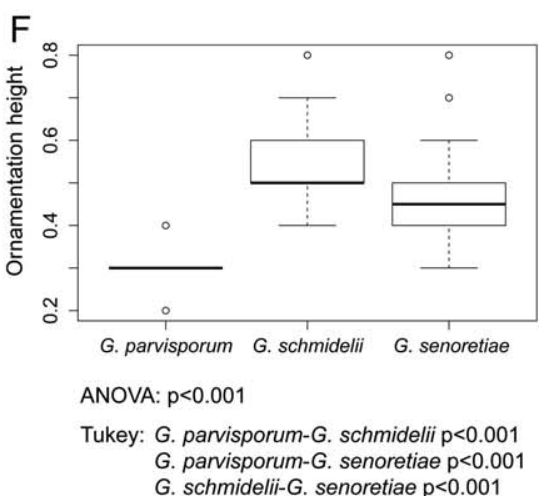

FIG. 2. Boxplots of six measured morphological characters and significance indices for ANOVA and Tukey's HSD tests. A. Exoperidia diameter. B. Endoperidia diameter. C. Stalk height. D. Number of peristome folds. E. Basidiospore diameter. F. Basidiospore ornamentation height.

TYPE-AH 19559!, ISOTYPE-herb. M.M. Dios Catamarca 25). Ibidem, 3-VI-1994, H. Villafañe (PARATYPE-AH 19560!, ISOPARATYPE-herb. M.M. Dios Catamarca 26).

Complete description: Dios et al. (2000).

Synoptic description: Exoperidium arched, not truly hygrometric, 20-40 mm diam; mycelial layer encrusting debris. Endoperidium 8-12 mm diam, shortstalked, stalk 0.5-2 mm high; surface minutely rough, with low and irregular warts, with faint pruina in young basidiomata. Mesoperidium almost indistinct, reduced to sparse irregular small crystals and generative hyphae. Peristome sulcate, with 11-22 folds, more or less distinctly delimited. Basidiospores globose, 3.5-4.5 $\mu \mathrm{m}$ diam, with $0.2-0.4 \mu \mathrm{m}$ high warts. Capillitium up to $6 \mu \mathrm{m}$ wide. Pseudoparenchymatous layer with thin-walled hyphal cells.

Ecology and distribution: Confirmed records of this species are known from tropical and subtropical grasslands, savannahs and shrub lands biome of the Neotropic ecozone (Olson et al. 2001). (Concerning the Moreno et al. 2010 record, see Discussion.)

Geastrum schmidelii Vittad., Monographia Lycoperdineorum: 13. 1842, "Geaster"

FIG. 3B
Lectotype: (designated here): Fig. VII of plate I in Vittadini (1842).

= G. nanum Pers., J. Bot. (Desvaux) 2:27. 1809, nom. illeg., Art. 52.1

Lectotype: (designated here): Fig. 3 of plate II in Persoon (1809).

= G. nanum var. coniferarum V.J. Staněk in Pilát, Flora ČSR B1, Gasteromycetes: 451. 1958

Holotype. CZECH REPUBLIC. Radotín, IX-1952, F. Pechar (PRM). Numerous paratypes were cited by Staněk (1958).

- G. rabenhorstii Kunze, Fungi selecti exsiccati 10. 1874, (as Geaster rabenhorstii), nom. inval. (Art. 38.1) Complete description: Sunhede (1989).

Synoptic description: Exoperidium arched, not truly hygrometric, 16-80 mm diam; mycelial layer encrusting debris. Endoperidium 3.5-22 mm diam, stalked; stalk 0.5-3 mm high; surface smooth and covered with a faint pruina. Mesoperidium not well developed, reduced to small crystals and generative hyphae, sometimes indistinct. Peristome sulcate, with 11-26(-28) folds, normally distinctly delimited. Basidiospores globose, 5-6.5(-7) $\mu \mathrm{m}$ diam, with $0.4-$ $0.7(-0.8) \mu \mathrm{m}$ high warts. Capillitium up to $7.5 \mu \mathrm{m}$ wide. Pseudoparenchymatous layer with thin-walled hyphal cells. 

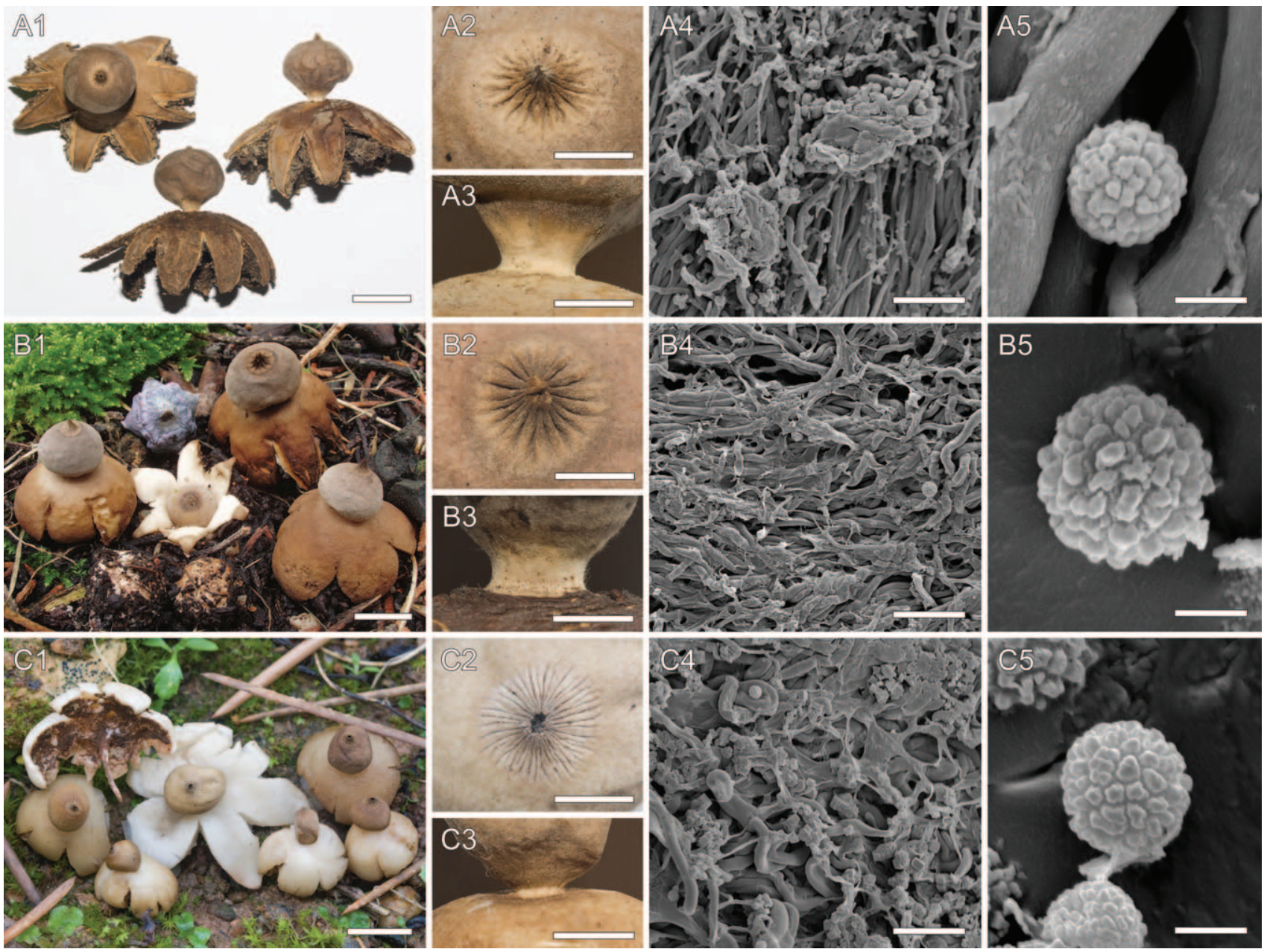

FIG. 3. Morphological characters of G. parvisporum, G. schmidelii and G. senoretiae. A. G. parvisporum (holotype, AH 19559). B. G. schmidelii (Zamora 279). C. G. senoretiae (holotype, MA-Fungi 86915). A1, B1, C1. Basidiomata habit, bar = $10 \mathrm{~mm}$. A2, B2, C2. Detail of the peristome, bar $=3 \mathrm{~mm}$. A3, B3, C3. Detail of the stalk, bar = $3 \mathrm{~mm}$. A4, B4, C4. Detail of the endoperidial surface under SEM, bar $=20 \mu \mathrm{m}$. A5, B5, C5. Basidiospores under SEM, bar $=2 \mu \mathrm{m}$.

Ecology and distribution: The studied specimens were found growing on both calcareous and siliceous soils, often associated with conifers (Pinus, Cupressus, Juniperus) but also broadleaf trees (Quercus). It is widely distributed through Europe (Sunhede 1989), and most records are from Mediterranean forests, woodlands and scrub, temperate conifer forests, temperate broadleaf and mixed forests and Boreal forests/taiga biomes of the Paleartic ecozone. North American records in Bates (2004) would indicate, if confirmed, that it is also present in the Neartic ecozone, which seems likely.

Geastrum senoretiae J.C. Zamora, sp. nov. (FIGs. 3C, 4) MycoBank MB800471

Diagnosis: Exoperidium normally arched, not truly hygrometric, 13-31(-35) mm diam; mycelial layer encrusting debris. Endoperidium 3-8.5(-9) $\mathrm{mm}$ diam, shortstalked, stalk $0-0.8(-1) \mathrm{mm}$ high; surface glabrous and covered with a faint pruina. Mesoperidium poorly developed, reduced to sparse small crystals and generative hyphae. Peristome finely sulcate, with (19-)23-48(-65) shallow folds, $\leq 0.2 \mathrm{~mm}$ deep, mostly indistinctly delimited. Basidiospores globose, 4-5.5 $\mu \mathrm{m}$ diam, with 0.3-0.6(-0.8) $\mu \mathrm{m}$ high warts. Capillitium up to $7.5 \mu \mathrm{m}$ wide. Pseudoparenchymatous layer with thin-walled hyphal cells.

Type: SPAIN. JAÉN: Montizón, Venta de los Santos, on clayish soil, under Pinus pinaster, 7-XII-2010, J.C. Zamora, J. Señoret Ẽ B. Zamora, Zamora 450 (HOLOTYPE-MAFungi 86915!, ISOTYPES-AH 44862!, UPS!).

Etymology: The epithet is dedicated to Juana Señoret, an excellent collaborator and mother of the first author.

Macromorphological description: Basidiomata subglobose just before expansion, hypogeal. Exoperidium splitting into 4-8 unequal rays, 13-31(-35) mm diam when forced in horizontal position, normally arched but sometimes planar, not saccate when mature, not hygrometric although some basidiomata may show the tips of the rays curved to the endoperidial body. 


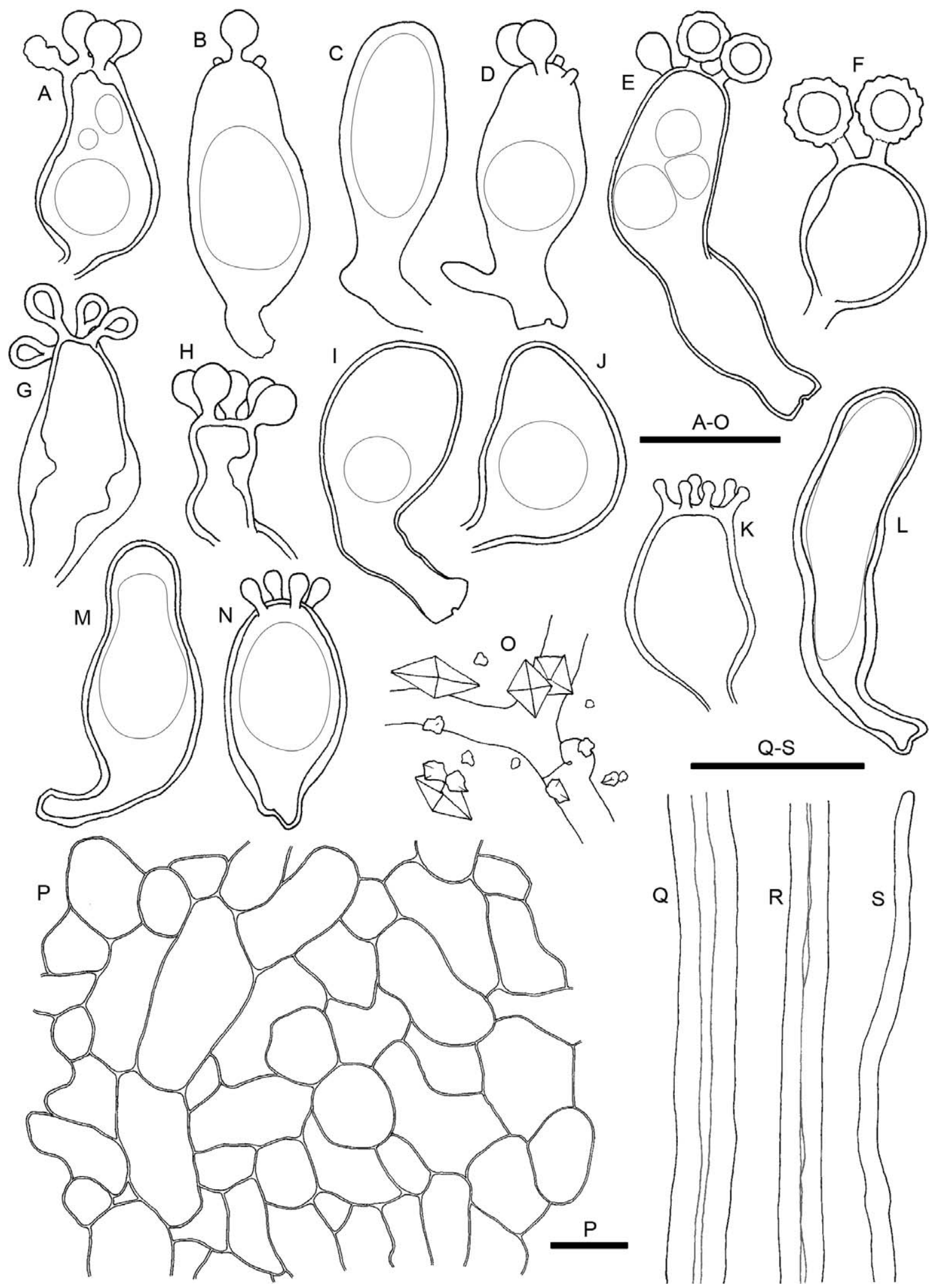

FIG. 4. Light microscope drawings of Geastrum senoretiae holotype (MA-Fungi 86915). A-N. Sclerified basidia. O. Thinwalled, clamped hypha and crystals from the endoperidial surface. P. Cells from the pseudoparenchymatous layer. Q-S. Capillitium. Bars: A-O $=10 \mu \mathrm{m}, \mathrm{P}=25 \mu \mathrm{m}, \mathrm{Q}-\mathrm{S}=20 \mu \mathrm{m}$. 
Mycelial layer thin, whitish to pale cream, strongly intermixed with debris from the substrate, attached to the fibrous layer (rarely peeling off in some areas). Rhizomorphs sometimes present, up to $9 \mathrm{~mm}$ long, whitish, and intermixed with debris. Fibrous layer in most cases papyraceous when denuded (seen in old basidiomata), sometimes moderately coriaceous, whitish to cream. Pseudoparenchymatous layer whitish to pale cream in newly expanded, fresh basidiomata, soon cream to ochraceous cream, later ochraceous brown to brownish, darker when dried, frequently cracked, attached to the fibrous layer, up to $1.5 \mathrm{~mm}$ thick when fresh, $<0.2 \mathrm{~mm}$ thick in dry state, not persistent. Endoperidium subglobose to ovoid, sometimes irregular, 3-8.5(-9) mm diam, pale ochraceous brown to dark grayish brown; endoperidial surface normally glabrous or almost so, rarely with scattered and short protruding hyphae, with small crystals in young basidiomata. Peristome finely plicate, with the same color as the endoperidium or slightly lighter or darker, conical to almost flat, rarely irregular, $<0.5-$ $1.5(-2) \mathrm{mm}$ high, indistinctly to faintly delimited, with (19-)23-48(-65) shallow folds, $\leq 0.2 \mathrm{~mm}$ deep, sometimes reduced to irregular ridges; ostiole often fimbriate. Stalk short, $0-0.8(-1) \mathrm{mm}$ high, whitish to cream. Apophysis absent or poorly developed, with the same color or slightly lighter than the rest of the endoperidium. Mature gleba dark grayish brown. Columella weak, subglobose to broadly ellipsoid, about $1.5-3 \mathrm{~mm}$ high.

Micromorphological description: Basidiospores globose, 4-5.5 $\mu \mathrm{m}(\mathrm{n}=200)$ diam including ornamentation, brownish to yellowish brown, with $0.3-0.6$ $(-0.8) \mu \mathrm{m}$ high brown warts. Sclerified basidia sporadic, $10-22.5 \times 6-10.5 \mu \mathrm{m}$ (stalk not included), with $1.5-6 \mu \mathrm{m}$ long stalk, rarely not stalked, ellipsoid to clavate, rarely subglobose; complete clamps not observed at basis, but a basal "clamp scar" often visible; the majority with cytoplasmic drops; thin- to thick-walled; walls almost hyaline to brownish; with 26 apical 1-2 $\mu \mathrm{m}$ long sterigmata. Capillitial hyphae 3$7.5 \mu \mathrm{m}$ wide, aseptate, rarely branched, most of them straight, thick-walled (walls 1.5-3 $\mu \mathrm{m}$ thick), with narrow lumen; tips acute to rounded, about 1-2.5 $(-3) \mu \mathrm{m}$ diam; surface naked or encrusted with debris. Prismatic crystals up to $10 \times 7 \mu \mathrm{m}$, and bipyramidal crystals up to $12 \mu \mathrm{m}$ diam, sometimes present in mature gleba. Endoperidium composed of 5-11 $\mu \mathrm{m}$ wide, brownish to yellowish brown, aseptate, most of them unbranched, slightly sinuous, strongly intertwined, thick-walled (walls 1.5-4 $\mu \mathrm{m}$ ) hyphae, with visible lumen; surface normally with few protruding hyphae, not well differentiated from the rest, $7-13 \mu \mathrm{m}$ wide, and some bipyramidal crystals, about 5-15 $\mu \mathrm{m}$ diam. Peristomal hyphae (5-)6-11 $\mu \mathrm{m}$ wide, aseptate, the majority unbranched, thick-walled (walls 2$3.5 \mu \mathrm{m})$, lumen visible, slightly sinuous, narrowing at base and apex, tips mostly rounded, a few acute, (2.5-) $3-5(-6.5) \mu \mathrm{m}$ diam; surface more or less naked or with a few encrusted debris. Mesoperidium difficult to discern, present at least in the youngest basidiomata but reduced, consisting of 2-15 $\mu \mathrm{m}$ diam bipyramidal crystals and a few (2-)2.5-3 $\mu \mathrm{m}$ wide, hyaline, branched, thin-walled, clamped hyphae. Pseudoparenchymatous layer of thin-walled (walls ca. $1 \mu \mathrm{m}$ thick), hyaline to yellowish cells, variable in shape and size, about 35-90(-100) $\mu \mathrm{m}$ diam. Fibrous layer with 3.5$7(-7.5) \mu \mathrm{m}$, hyaline to yellowish, aseptate, straight or slightly sinuous, intertwined, normally unbranched, thick-walled (walls 1.5-2.5 $\mu \mathrm{m}$ thick) hyphae; lumen visible. Mycelial layer double-layered; inner layer consisting of 2-4 $\mu \mathrm{m}$ wide, strongly glued together, more or less hyaline, branched, thin-walled and clamped hyphae; outer layer with 1.5-3.5(-4) $\mu \mathrm{m}$ wide, hyaline to somewhat yellowish, aseptate, rarely branched, comparatively more or less thick-walled (walls $0.5-1.5 \mu \mathrm{m}$ thick) hyphae, lumen narrow and difficult to perceive. Rhizomorphs mainly made up of 1-3 $\mu \mathrm{m}$ wide, hyaline to slightly yellowish, aseptate, sparsely branched, comparatively thick-walled (walls ca. $0.5-1.5 \mu \mathrm{m}$ thick) hyphae, without lumen or with an almost indistinct lumen; some thin-walled, clamped hyphae present in the core; rose-like aggregates of bipyramidal crystals on the surface.

Comments on sclerified basidia: The discovery of sclerified basidia (basidia with thick walls) in the gleba mass of the G. senoretiae type material (FIG. 4A$\mathrm{N}$ ) is of great interest, in that Geastrum basidia are usually thin-walled and disintegrate as soon as basidiospores are almost mature, before the gleba mass is fully pigmented (Sunhede 1989). Previous reports of this kind of basidium in Geastrum have not been found. The "metamorphosed basidia" described by Dring (1964) are unlikely to be any kind of basidia or, at least, they are certainly different from those that have been observed here. In any case, these sclerified basidia are probably inconstant elements that have remained in the gleba mass, perhaps due to an abnormal maturation. The morphology is close to other species, particularly G. schmidelii (Sunhede 1989), which is in accordance with the phylogenetic position of G. senoretiae (FIG. 1). However, at present we prefer to be cautious and not to attach taxonomic value to this type of basidium because they may be not representative of the basidia present in immature basidiomata. Further studies involving immature fruit bodies may provide new information to solve this question.

Ecology and distribution: The species was found in disturbed localities of "Iberian sclerophyllous and 
semi-deciduous forests", and "Northeastern Spain and Southern France Mediterranean forests" ecoregions (Mediterranean forests, woodlands and scrub biome of the Paleartic ecozone) (Olson et al. 2001). Those areas are located on clayish or sandy, and neutral or slightly acidic soils, where Quercus rotundifolia Lam. should be the dominant species but actually are composed by Cistus shrubs and planted Pinus trees among some Quercus trees, with patches of naked soil in the most degraded parts. Geastrum senoretiae is known only from the Iberian Peninsula, being an uncommon but widespread species, due to its presence in five non-contiguous provinces.

\section{DISCUSSION}

Reassessment of Geastrum schmidelii var. parvisporum.-According to the results, the holotype specimen of G. schmidelii var. parvisporum is not closely related to $G$. schmidelii var. schmidelii in phylogenetic analyses (FIG. 1), but with two specimens previously included in sect. Hariotia by Zamora et al. (2014). While close in terms of several macromorphological characters (FIG. 3), the taxonomic position of both taxa is explained by the different basidiospore features, specifically the much smaller diameter and the less marked ornamentation, with lower warts (FIGS. 2, 3). Furthermore, the endoperidial surface of the G. schmidelii var. parvisporum holotype is slightly asperate with minute and irregular warts in the well conserved parts (FIG. 3A4) and smooth in G. schmidelii var. schmidelii. This character was not indicated by Dios et al. (2000) when they described the taxon, but it should be noticed that such warts are extremely inconspicuous and they disappear easily in exposed areas and old basidiomata. Both morphological characters, basidiospore features and endoperidial surface, have been shown to be of taxonomic significance for infrageneric subdivisions of the genus (Zamora et al. 2014) and justify the inclusion of G. schmidelii var. parvisporum in sect. Hariotia instead of sect. Schmidelia. Therefore G. schmidelii var. parvisporum is considered a different species, and it has been named as such in the taxonomic part.

Two specimens included in molecular analyses are closely placed with the holotype of G. parvisporum (FIG. 1). One of them has nearly identical sequence data, and it is also morphologically indistinguishable from both the holotype and the paratype of $G$. parvisporum. Thus, this specimen is considered conspecific. In addition, we have studied a rich collection from Córdoba (Argentina) that also agrees morphologically with this taxon. However, the other specimen included in the molecular analyses shows more discrepancies in sequence data (FIG. 1), and it is morphologically divergent mainly due to the presence of more conspicuous and more or less dark, rounded warts on the endoperidial surface, as well as a lower number of thick peristome folds (7-12). This specimen may represent a different taxon and therefore we relegate it as affined until more samples are available for morphological and molecular studies. For this reason, this specimen was not included in the morphological comparative analysis or in the description of G. parvisporum. Moreno et al. (2010) published a North American record of G. schmidelii var. parvisporum, from Mexico. The ecology of the cited specimen is clearly different to the specimens included in the present study as G. parvisporum, in that it was found in the Neartic ecozone, among Quercus and Cupressus litter. Basidiospores are slightly bigger $(4.5-5[-5.5] \mu \mathrm{m}$ diam) and the ornamentation is not so dense. Therefore, further data of the Mexican specimen and newly collected material, including DNA sequences, would be desirable for a definite taxonomic placement of this sample.

Likewise several American reports of G. schmidelii with small basidiospores (e.g. Lloyd 1902, Coker and Couch 1928, Smith 1951) should be checked to identify possible misidentifications of morphologically close taxa. Nevertheless not all reports of American G. schmidelii have an unusual basidiospore size, because the morphology of the North American specimens of G. schmidelii studied by Bates (2004) precisely agrees with that of the European specimens included in our study. As shown by Sunhede (1989), $G$. schmidelii is a variable species, and it has been described under other names such as G. nanum Pers. (nom. illeg.) and G. nanum var. coniferarum V.J. Staněk. After studying the protologs and original material of these taxa, we are of the opinion that the cited names should be treated as heterotypic synonyms (see G. schmidelii in TAXONOMY). The name Geastrum rabenhorstii Kunze seems to be invalidly published because Johs. Kunze Fungi selecti exsiccati or subsequent references to this name (e.g. Rabenhorst 1876) do not contain a diagnosis.

Geastrum senoretiae as a second species in Geastrum sect. Schmidelia.-The new species G. senoretiae is easily differentiated on account of the combination of its macroscopic characteristics (i.e. the small size, non-hygrometric exoperidium, subsessile to slightly stalked endoperidial body, finely plicate, indistinctly delimited peristome, absent or poorly developed mesoperidium and the mycelial layer that encrusts debris). However, in the MA-Fungi herbarium, some 
specimens of $G$. senoretiae had been identified as $G$. elegans and G. kotlabae.

Geastrum elegans (Vittadini 1842) basidiomata are of the same size or slightly larger than G. senoretiae, have a non-hygrometric exoperidium, sessile endoperidium and plicate peristome, but can be distinguished by the well developed mesoperidium, always present when young, peristome with fewer (10-20 [-26]) and deeper folds, and the often saccate exoperidium. In addition, basidiospores are slightly larger, the rays often are recurved under the exoperidial disk, and the myceliar layer peels off more easily (Sunhede 1989). It is an isolated species, the only member of Geastrum sect. Elegantia (Zamora et al. 2014). The phylogenetic reconstruction showed $G$. elegans more closely related to G. kotlabae, in agreement with previous results of Zamora et al. (2014), and standing on a rather long branch clearly differentiated from G. senoretiae (FIG. 1). Nevertheless, small, weathered basidiomata of G. elegans, with no or few remnants of the mesoperidium, can be easily misidentified; in that case, the peristoma features are the most reliable morphological characters to separate both species.

Geastrum kotlabae (Staněk 1958) is clearly different from $G$. senoretiae because of the strongly hygrometric, non-arched exoperidium, mycelial layer that easily peels off, persistent pseudoparenchymatous layer, with thick-walled cells, endoperidial surface rough to furfuraceous when young, peristome with fewer (822[-27]) and deeper folds (unless abnormal) and larger basidiospores (Staněk 1958, Sunhede 1989). This species belongs to Geastrum sect. Campestria J.C. Zamora (Zamora et al. 2014). As previously indicated, G. kotlabae is more closely related to G. elegans than to G. senoretiae and also placed on a long branch (FIG. 1).

Geastrum minimum (Schweinitz 1822) also resembles G. senoretiae by its small size and habit. Furthermore, both species have been found growing close together in the type locality, only a few meters apart. However, G. minimum is readily characterized by the fibrillose and usually distinctly delimited peristome, often bigger crystals on the endoperidial surface, distinctly stalked endoperidial body, and larger basidiospores (Sunhede 1989). Even if Zamora et al. (2014) showed two different clades of specimens with the provisional name "G. minimum", both clades belong to Geastrum sect. Geastrum, which is not closely related to Geastrum sect. Schmidelia in present (FIG. 1) or previous (Zamora et al. 2014) phylogenetic analyses.

The closest species to G. senoretiae is G. schmidelii (Vittadini 1842), which differs in the distinct stalk, normally well delimited peristome, with fewer (11-
26[-28]) and deeper folds, and larger basidiospores (FIGS. 2, 3). Our results also showed significant differences in exoperidial and endoperidial sizes and in ornamentation height, but considerable overlap exists (FIG. 2). According to Sunhede (1989), the diameter of the exoperidium can reach up to $80 \mathrm{~mm}$ when horizontally mounted, but very small to small basidiomata are common as well. The significant differences found in ornamentation height are due to the high number of approximate measurements performed, but considering the wide overlap and that those differences are in the order of tenths of micrometers, we can only say that basidiospores of G. schmidelii tend to be slightly more ornamented than in $G$. senoretiae. The sulcate peristome, even endoperidial surface, poorly developed mesoperidium, more or less stalked endoperidial body, and arched exoperidium are the characteristics shared by G. schmidelii and G. senoretiae that justify the inclusion of both species in Geastrum sect. Schmidelia, as first indicated by Zamora et al. (2014).

\section{ACKNOWLEDGMENTS}

The first author thanks the Consejo Superior de Investigaciones Científicas for supporting his research with a predoctoral grant (JAE-Pre 2010), J. Diéguez-Uribeondo for financial support with the SEM, Y. Ruiz for technical assistance with SEM and J.M. García-Martín for kindly revising the English. Curators of the herbaria AH, CORD, MA-Fungi, S, UPS, as well as collectors are acknowledged for their great help with the study and for providing cited specimens.

\section{LITERATURE CITED}

Baseia IG, Calonge FD. 2006. Geastrum hirsutum: a new earthstar fungus with a hairy exoperidium. Mycotaxon 95:301-304.

—, Milanez AI. 2003. Geastrum setiferum (Gasteromycetes): a new species with a setose endoperidium. Mycotaxon 84:135-140.

Bates ST. 2004. Arizona members of the Geastraceae and Lycoperdaceae (Basidiomycota, Fungi) [master's thesis]. Arizona State Univ. Press. 435 p.

Borchsenius F. 2007. FastGap 1.0.8. Software distributed by the author. http://192.38.46.42/aubot/fb/FastGap_home. htm (accessed 1 Nov 2012)

Calonge FD. 1998. Gasteromycetes I. Lycoperdales, Nidulariales, Phallales, Sclerodermatales, Tulostomales. Flora Mycol Iber 3:1-271.

, Mata M. 2004. A new species of Geastrum from Costa Rica and México. Bol Soc Micol Madrid 28:331335 .

Carranza J. 2005. Contribución al catálogo de los Gasteromycetes (Basidiomycotina, Fungi) de Costa Rica. Anal Jard Bot Madrid 62:23-45.

— Z Zamora JC. 2003. Geastrum arenarium, encontrado 
en España y nuevo para Europa. Bol Soc Micol Madrid 27:59-61.

Castresana J. 2000. Selection of conserved blocks from multiple alignments for their use in phylogenetic analysis. Mol Biol Evol 17:540-552, doi:10.1093/ oxfordjournals.molbev.a026334

Coker WC, Couch JN. 1928. The Gasteromycetes of the eastern United States and Canada. Chapel Hill: Univ. N. Carolina Press. 201 p +123 plates.

Darriba D, Taboada GL, Doallo R, Posada D. 2012. jModelTest 2: more models, new heuristics and parallel computing. Nat Methods 9:772, doi:10.1038/nmeth. 2109

Dios MM, Moreno G, Altés A, D’Angelo MV. 2000. Algunos Gasteromycetes interesantes de Catamarca, Argentina. Micologia 2000:155-164.

Dörfelt H, Kiet TT, Berg A. 2004. Neue MakromycetenKollektionen von Vietnam und deren systematische und ökogeographische Bedeutung. Feddes Repertorium 115:164-177, doi:10.1002/fedr.200311034

Douanla-Meli C, Lange E, Calonge FD. 2005. Geastrum pleosporus sp. nov., a new species of Geastraceae identified by morphological and molecular phylogenetic data. Mycol Prog 4:239-250, doi:10.1007/s11557-006-0127-3

Dring DM. 1964. Gasteromycetes of west tropical Africa. Mycol Pap 98:1-60.

Fazolino EP, Calonge FD, Baseia IG. 2008. Geastrum entomophilum, a new earthstar with an unusual spore dispersal strategy. Mycotaxon 104:449-453.

Felsenstein J. 1985. Confidence limits on phylogenies: an approach using the bootstrap. Evolution 39:783-791, doi: $10.2307 / 2408678$

Gardes M, Bruns TD. 1993. ITS primers with enhanced specificity for basidiomycetes. Application to the identification of mycorrhizae and rusts. Mol Ecol 2: 113-118, doi:10.1111/j.1365-294X.1993.tb00005.x

Hall TA. 1999. BioEdit: a user-friendly biological sequence alignment editor and analysis program for Windows 95/98/NT. Nucleic Acids Symp Ser 41:95-98.

Hemmes DE, Desjardin DE. 2011. Earthstars (Geastrum, Myriostoma) of the Hawaiian Islands including two new species, Geastrum litchiforme and Geastrum reticulatum. Pac Sci 65:477-496, doi:10.2984/65.4.477

Hillis DM, Bull JJ. 1993. An empirical test of bootstrapping as a method for assessing confidence in phylogenetic analyses. Syst Biol 42:182-192, doi:10.1093/sysbio/ 42.2 .182

Hosaka K, Bates ST, Beever RE, Castellano MA, Colgan W, Domínguez LS, Nouhra ER, Geml J, Giachini AJ, Kenney SR, Simpson NB, Spatafora JW, Trappe JM. 2007 [2006]. Molecular phylogenetics of the gomphoid-phalloid fungi with an establishment of the new subclass Phallomycetidae and two new orders. Mycologia 98:949-959, doi:10.3852/mycologia.98.6.949

— Castellano MA. 2008. Molecular phylogenetics on Geastrales with special emphasis on the position of Sclerogaster. Bull Natl Mus Nat Sci, Ser B 34:161-173.

Jeppson M, Nilsson RH, Larsson E. 2013. European earthstars in Geastraceae (Geastrales, Phallomycetidae) - a systematic approach using morphology and molecular sequence data. Syst Biodivers 11:437-465, doi:10.1080/14772000.2013.857367

Kasuya T, Hosaka K, Uno K, Kakishima M. 2012. Phylogenetic placement of Geastrum melanocephalum and polyphyly of Geastrum triplex. Mycoscience 53:411426, doi:10.1007/S10267-012-0186-Z

Katoh K, Misawa K, Kuma K, Miyata T. 2002. MAFFT: a novel method for rapid multiple sequence alignment based on fast Fourier transform. Nucleic Acids Res 30: 3059-3066, doi:10.1093/nar/gkf436

Kirk PM, Cannon PF, Minter DW, Stalpers JA, eds. 2008. Ainsworth and Bisby's Dictionary of the Fungi, 10th ed. Wallingford, UK: CABI Europe. 771 p.

Kretzer A, Bruns TD. 1999. Use of atp6 in fungal phylogenetics: an example from the Boletales. Mol Phylogenet Evol 13:483-492, doi:10.1006/mpev. 1999.0680

Kuhar F, Castiglia V, Papinutti L. 2013. Geastrum species of the La Rioja province, Argentina. Mycotaxon 122:145156, doi:10.5248/122.145

— noticeable species with red-violet exoperidium. Mycologia 101:535-538, doi:10.3852/08-029

Lewis PO. 2001. A likelihood approach to estimating phylogeny from discrete morphological character data. System Biol 50:913-925, doi:10.1080/106351501753462876

Lloyd CG. 1902. The Geastrae. Bull Lloyd Libr Bot, Pharm. Materia Med 2:1-43.

Lutzoni F, Kauff F, Cox CJ, McLaughlin D, Celio G, Dentinger B, Padamsee M, Hibbett D, James TY, Baloch E, Grube M, Reeb V, Hofstetter V, Schoch C, Arnold E, Miadlikowska J, Spatafora J, Johnson D, Hambleton S, Crockett M, Shoemaker R, Sung G-H, Lücking R, Lumbsch T, O'Donnell K, Binder M, Diederich P, Ertz D, Gueidan C, Hansen K, Harris RC, Hosaka K, Lim Y-W, Matheny B, Nishida H, Pfister D, Rogers J, Rossman A, Schmitt I, Sipman H, Stone J, Sugiyama J, Yahr R, Vilgalys R. 2004. Assembling the Fungal Tree of Life: progress, classification and evolution of subcellular traits. Am J Bot 91:14461480, doi:10.3732/ajb.91.10.1446

Martín MP, Winka K. 2000. Alternative methods of extracting and amplifying DNA from lichens. Lichenologist 32:189-196, doi:10.1006/lich.1999.0254

Matheny PB, Liu YJ, Ammirati JF, Hall BD. 2002. Using RPB sequences to improve phylogenetic inference among mushrooms (Inocybe, Agaricales). Am J Bot 89:688-698, doi:10.3732/ajb.89.4.688

Médail F, Quézel P. 1997. Hot-spots analysis for conservation of plant biodiversity in the Mediterranean Basin. Annals Missouri Bot Gard 84:112-127, doi:10.2307/ 2399957

Moreno G, Lizárraga M, Esqueda M, Coronado ML. 2010. Contribution to the study of gasteroid and secotioid fungi of Chihuahua, Mexico. Mycotaxon 112:291-315, doi:10.5248/112.291

Myers N, Cowling R. 1999. Mediterranean Basin. In: Mittermeier RA, Myers N, Mittermeier GC, eds. Hotspots-Earth's biologically richest and most endan- 
gered terrestrial ecoregions. Mexico City: CEMEX \& Conservation International. p 254-267.

Olson DM, Dinerstein E, Wikramanayake ED, Burgess ND, Powell GVN, Underwood EC, D'Amico JA, Strand HE, Morrison JC, Loucks CJ, Allnutt TF, Lamoreux JF, Ricketts TH, Itoua I, Wettengel WW, Kura Y, Hedao P, Kassem K. 2001. Terrestrial ecoregions of the world: a new map of life on Earth. BioScience 51:933-938, doi:10.1641/ 0006-3568(2001)051 [0933:TEOTWA]2.0.CO;2

Persoon CH. 1801. Synopsis methodica Fungorum. Göttingen, Germany, 106 p.

. 1809. Mémoire sur les Vesse-Loups ou Lycoperdon. J Bot (Desvaux) 2:5-31.

R Development Core Team. 2008, R: A language and environment for statistical computing. Vienna, Austria: $\mathrm{R}$ Foundation for Statistical Computing. ISBN 3900051-07-0 (http://www.R-project.org).

Rabenhorst L. 1876. Fungi Europaei Cent. 21 und 22. Hedwigia 15:103-112.

Rambaut A. 2007. Molecular evolution, phylogenetics and epidemiology. FigTree. http://tree.bio.ed.ac.uk/ software/figtree/ (accessed: 1 Oct 2012)

— Suchard MA, Xie D, Drummond AJ. 2013. Tracer 1.5. (available at http://beast.bio.ed.ac.uk/Tracer)

Ronquist F, Teslenko M, van der Mark P, Ayres DL, Darling A, Höhna S, Larget B, Liu L, Suchard MA, Huelsenbeck JP. 2012. MrBayes 3.2: efficient Bayesian phylogenetic inference and model choice across a large model space. Syst Biol 61:539-542, doi:10.1093/sysbio/sys029

Sarasini M. 2005. Gasteromiceti Epigei. Trento/Vicenza, 406 p.

Schweinitz LD. 1822. Synopsis fungorum Carolinae superioris secundum observationes. Denkschr Schweiz Naturforsch Ges 1:20-130.

Simmons MP, Ochoterena H. 2000. Gaps as characters in sequence-based phylogenetic analyses. Syst Biol 49:369381, doi:10.1093/sysbio/49.2.369

Smith AH. 1951. Puffballs and their allies in Michigan. Ann Arbor: Univ. Michigan Press. 131 p.

Stamatakis A. 2006. RAxML-VI-HPC: maximum likelihoodbased phylogenetic analyses with thousands of taxa and mixed models. Bioinformatics 22:2688-2690, doi:10.1093/ bioinformatics/btl446
Staněk VJ. 1958. Geastraceae. In: Pilát A, ed. Flora ČSR B1, Gasteromycetes. Poland: Praha. p 392-526, 777-795.

Stiller JW, Hall BD. 1997. The origin of red algae: implications for plastid evolution. Proc Natl Acad Sci USA 94:4520-4525, doi:10.1073/pnas.94.9.4520

Sunhede S. 1989. Geastraceae (Basidiomycotina): morphology, ecology and systematics with special emphasis on the North European species. Synopsis Fungorum 1:1534.

Swofford DL. 2003. PAUP* 4.0b10: phylogenetic analysis using parsimony (*and other methods). Sunderland, Massachusetts: Sinauer Associates.

Thiers B. [continuously updated]. Index herbariorum: a global directory of public herbaria and associated staff. New York Botanical Garden's Virtual Herbarium. (http://sweetgum.nybg.org/ih/)

Vilgalys R, Hester M. 1990. Rapid genetic identification and mapping of enzymatically amplified DNA from several Cryptococcus species. J Bacteriol 172:4238-4246.

Vittadini C. 1842. Monographia Lycoperdineorum. Torino, Italy, $93 \mathrm{p}$.

White TJ, Bruns T, Lee S, Taylor J.. Amplification and direct sequencing of fungal ribosomal RNA genes for phylogenetics. In: Innis M, Gelfand J, Sninsky J, White T. PCR protocols: a guide to methods and applications. Orlando, Florida: Academic Press. p 315-322.

Zamora JC, Calonge FD. 2007. Geastrum parvistriatum, una nueva especie encontrada en España. Bol Soc Micol Madrid 31:139-149.

- - - Hosaka K, Martín MP. 2014. Systematics of the genus Geastrum (Basidiomycota, Fungi) revisited. Taxon 63:477-497.

- - Martín MP. 2013. New sources of taxonomic information for earthstars (Geastrum, Geastraceae, Basidiomycota): phenoloxidases and rhizomorph crystals. Phytotaxa 132:1-20, doi:10.11646/phytotaxa. 132.1.1

Zwickl DJ. 2006. Genetic algorithm approaches for the phylogenetic analysis of large biological sequence datasets under the maximum likelihood criterion [doctoral dissertation]. Austin: Univ Texas Press. 115 p. 